ISSN 2413-0877 Volume 3 (2016) 61-66

ICoA Conference Proceedings, 7 - 9 November 2015

\title{
Shifting From Dichotomy to Dualism: The Way to Survive the Indonesia's Economy
}

\author{
Mochammad Maksum Machfoedz \\ Department of Agro-industrial Technology, Faculty of Agricultural Technology \\ Universitas Gadjah Mada, Jl. Flora No.1 Bulaksumur 55281, Indonesia. \\ Email: maksum_ugm@yahoo.com*
}

\begin{abstract}
The Indonesia financial crisis in 1997 was an event waiting to happen very long before being precipitated by the Asian crisis. Such a collapse has its root in a development model imposed by a monolithically authoritarian government basically rooted on the topdown development model, the import-based industrial development, and the non-agro industrialization. Any policy measures, monetary-fiscal-trade policies, adopted by the government were generally in favor of import-based industry, IBI, but at the expense of agricultural and local-based economy. Based on an approximately the same scenario, the country's crisis 2015 lasted longer since the collapse of local currency starting in May 2013. Among several differences, the most significant was the nature of capital flight. Such capital flight in 1997 was basically due to the major need to US dollars for foreign debt payment, whereas that in 2015 was principally due to remarkable economic prospect outside after its collapse following the Greek crisis. The adoption of dichotomy model in economy, protecting extremely strong dependence of the Indonesia economy on the IBI, sacrificing the domestic-based-industry, DBI, has been the central criticisms against the country's economy as relatively unstable, centralized in Jakarta only, and having minimum value added. Challenging the weaknesses of such an economic model, the country should have been adopting the model of economic dualism positioning IBI and $\mathrm{DBI}$ as dual sectors having the same importance
\end{abstract}

Keywords: Economic dichotomy, Economic dualism, DBI, IBI.

\section{INTRODUCTION}

Since the earliest days of his presidency supported by his Cabinet, named as the Working Cabinet, President Joko Widodo, has been facing serious economic problems characterized by the drop in local currency. Such an economic collapse was in fact started in the mid of 2013, long before his induction, 20 October 2014. However, continuing impact of that such a local currency drop has been lasting until the end of this year, November 2015, without any significant symptom when to terminate. The Rupiah exchange rate dropped seriously from Rp 9,620 per US Dollar in January 2013 and Rp 10,333 early August 2013, to 12,191 at the end of 2013 (Subekti, 2013), escalated to $\mathrm{Rp} 14,700$ in September and down back to Rp 13, 680 per US Dollar, early November 2015.

This monetary crises, reminded us of about the same crises right before Reformation
Government, 1997-1998. That financial crisis finally followed by the downfall of the previous government after ruling the country for three decades. During this period the Indonesian currency seriously dropped about 83.6 percent from Rp 2,432 in July 1997 to Rp 14,800 per US Dollar, 24 January 1998, and settled down to Rp 7,450 per US Dollar, early 2000, after escalated wildly (Jung et al, 2003). Only in less than fifteen years the country experienced two extremely devastating monetary crisis, the crisis ended in 2000 and that started in 2013.

Such an experience of the Republic for having two monetary crisis within a relatively very short development period is a very interesting lesson to learn. And therefore, this paper is aimed at assessing qualitatively the ultimate reason behind the two 


\section{THE COUNTRY ECONOMY, BEFORE 2000}

The success of the country's economic development in 1970s strongly supported by three remarkable factors, mainly, windfall profit from oil boom, escalating foreign loan, and increasing foreign direct investment, has been followed by the country's success in industrialization, 1980s. Unfortunately, industrial choice of the government was made with an extremely strong bias to the skilledlabor, high technology, and capital intensive industries, SLI-HTI-CII, which were generally very foreign-based in nature (Jung, et.al, 2003).

Logical consequence of prioritizing foreign-based industries or import-based industry, IBI, was the marginalization of domestic-based industries, DBI, including agriculture. While IBI was characterized by SLI-HTI-CII, DBI was marked by its ULIATI-LII, unskilled-labor, appropriatetechnology, and labor intensive industries. Any extreme measure including monetary-fiscaltrade policies supporting FBI would automatically victimize DBI. The IBI has been very successful at the expense of DBI. In turns, comparative advantage naturally blessed to agricultural sector has never reached its global competitiveness.

It was the economic success long before 2000. After the success, following the downfall of oil boom, and approaching 2000, the capacity to protect IBI was getting worse and worse due to limited foreign reserves for Rupiah protection and expanding need for foreign exchange for debt payment. These two had, hand in hand, shared significant contribution to the Indonesian monetary crisis 1997-1998, joining the Asian crisis characterized by massive capital flight of Indonesia and the rest of Southeast Asian countries, following the floating of the Thai Baht, July 2, 1997. For Indonesia, the flight was even worse due to the failure of business sector in paying foreign debt because of unproductive investment decision (Jung et.al. 2003).

The Indonesia financial crisis 1997 was an event waiting to happen very long before being precipitated by the Asian crisis. Such a collapse has its root in a development model imposed by the monolithically authoritarian government for about three decades by the Indonesian development planner of the regime before the reformation era. It was basically rooted on the top-down development model, the import-based industrial development, the non-agro industrialization, and the rice-biased agricultural development (Jung et.al, 2003). Any policy, monetary-fiscal-trade policies, adopted by the government were generally in favor of import-based industry, IBI, but at the expense of agriculture in general, and localbased economy. After victimizing DBI the country then did not have any exit strategy to survive its economy.

\section{THE ECONOMIC SUCCESS 2001-2010}

General characteristics of the global economy 2001-2010 were not very optimistic in nature. Most countries were normally marked by minimum yearly growth rate and commonly rated under five percent. All over the world, according to Table 1, only three countries realizing the annual growth rate of above five percent, namely China, India, and Indonesia, at the growth rates of 11.7 percent, 5.7 and 5.2 percent, respectively. It was not very surprising due to the fact that popular countries experienced declining growth rate, 2001-2010, and many of them having negative growth rate during the second half of that decade following the collapse of the PIGS, a popular country abbreviation for Portugal, Ireland, Greece, and Spain.

Table 1. Annual Growth Rate, 2001-2010

\begin{tabular}{|l|c|l|c|}
\hline Country & $\begin{array}{c}\% \\
\text { Growth }\end{array}$ & Country & $\begin{array}{c}\% \\
\text { Growth }\end{array}$ \\
\hline China & 11.7 & Estonia & 3.8 \\
\hline India & 7.7 & Chile & 3.7 \\
\hline Indonesia & $\mathbf{5 . 2}$ & Brazil & 3.6 \\
\hline Russia & 4.9 & $\begin{array}{l}\text { South } \\
\text { Africa }\end{array}$ & 3.5 \\
\hline Slovakia & 4.9 & $\begin{array}{l}\text { Czech } \\
\text { Republic }\end{array}$ & 3,4 \\
\hline $\begin{array}{l}\text { South } \\
\text { Korea }\end{array}$ & 4.2 & Israel & 3.1 \\
\hline Turkey & 4.0 & Australia & 3.1 \\
\hline Poland & 3.9 & $\begin{array}{l}\text { Average } \\
\text { Rest }\end{array}$ & $\mathbf{1 . 7}$ \\
\hline
\end{tabular}

Source: Oberman, et.al. (2012)

The story behind the progress of several countries including Indonesia were escalating 
FDIs, foreign direct investments, flowing in the growing countries from the European countries, the United States, and other developed countries due to limited growth rate and strongly characterized by unstable economic growth. It was a significant blessing in disguise. Indonesia was being blessed massively with massive global capital inflow which has been very successful in providing remarkable growth rate as well as stabilizing power for the growth as it was summarized by Oberman et.al (2012), as shown in Table 2.

Table 2. GDP Growth, Standard Deviation, Annualized, 2001-2010

\begin{tabular}{|c|c|c|c|}
\hline Country & Percent & Country & Percent \\
\hline Indonesia & 0.9 & Canada & 1.8 \\
\hline Australia & 0.9 & India & 1.8 \\
\hline Portugal & 1.5 & $\begin{array}{l}\text { South } \\
\text { Korea }\end{array}$ & 2.0 \\
\hline Norway & 1.6 & Poland & 2.0 \\
\hline France & 1.6 & China & 2.0 \\
\hline $\begin{array}{l}\text { New } \\
\text { Zealand }\end{array}$ & 1.7 & $\begin{array}{l}\text { Netherla } \\
\text { nd }\end{array}$ & 2.1 \\
\hline Belgium & 1.7 & $\begin{array}{l}\text { United } \\
\text { States }\end{array}$ & 2.1 \\
\hline $\begin{array}{l}\text { Switzerla } \\
\text { nd }\end{array}$ & 1.8 & $\begin{array}{l}\text { Average } \\
\text { Rest }\end{array}$ & 3.4 \\
\hline
\end{tabular}

Source: Oberman, et.al. (2012)

The economic growth of Indonesia 20012010 was extremely very optimistic. However, due to the story behind the growth that has been summarized coupled with industrial selection of the country, the Indonesia's economy was criticized as having potential weaknesses and risks, because of the facts that such economic progresses were strongly influenced by the economic collapse of the other parts of the globe. To mention a few, popular criticisms were: (i) economy is relatively unstable, (ii) growth is centralized in Jakarta only, (iii) Indonesia follows the Asia Tiger's export-driven growth model, (iv) main economic driver is resources, and (v) growth has come largely from an expanding workforce (Oberman, et.al, 2012; Budiman, 2012).

It was very unfortunate that those five best criticisms containing meaningful lessons to learn were nullified by many Indonesian economists including Oberman at. al. (2012) from McKinzey Global Institute, economic advisory team to the Palace. Instead of adopting such the best lessons, Oberman et.al called them as irrelevant but a set of economic myths for Indonesia by providing their subjective rationality behind as the Palace Economic Adviser (Maksum, 2014).

Maksum (2014) explained further that due to IBI-biased, supported by raw material-based export strongly shouldered by expanding workforce, have made the country's economy highly dependent on foreign countries and, therefore relatively unstable. Whereas, IBIbiased strongly indicted the significant position of Jakarta and surrounding areas to be the growth centers leaving outer cities generally, and particularly outer island under developed. The potential for having unstable and centralized growth is not debatable.

Remaining criticisms, mentioning natural resources and expanding workforce as the drivers of economic growth of this nation were also very excellent criticisms. Natural resource dominance in export clearly indicated that meaningful added value of natural resources as well as human resources have been very minimum. This country has been donating remarkably huge amount of value added from natural as well as agricultural resource sector to their industrial processing outside Indonesia. Historical evidences also showed very clearly that the impact of IBI over-protection, resulted in significant competitiveness of DBI, especially ABI, agro-based industry, in producing raw material, directly lost their competitiveness.

He is also in agreement in accepting the first criticism based on the fact that the Indonesia's growth has been based on overall over-protective measures covering monetary, fiscal and trade policies, for the success of the IBI. Due to this protective measure therefore, the economy has been very dependent upon foreign economy. This view was supported by the weakening of Rupiah starting July 2013 (Maksum, 2012 and 2013). Furthermore, Maksum (2014) claimed that shifting from FBI to DBI and ABI would potentially guarantee the country's economic self-sufficiency, and in turns its growth stability.

The argument against the criticism mentioning that the growth is centralized in Jakarta only was very misleading. The use of the growth rate in developing the argument was not very suitable, based on the fact that the 
rate was the comparison between additional values gained during that period divided by initial value. Initial value of Jakarta economy is extremely huge and offsetting additional value in providing rate. Whereas, the absolute increase of the Jakarta economy is factually dominates Indonesia's growth and strongly concentrates the growth in Jakarta only. Decentralization of the growth to the outer Jakarta and the outer island would only be possible if, and only if, the country's development policy be reoriented to local potential based on the local and the sexiest resources, $\mathrm{ABI}$, agricultural-based industry.

In response to the remaining criticisms, the strongest driving force of the growth from natural resource and expanding workforce, should have been taken into serious account considering the fact that this country has been growing very fast through the support of the less added value of important export commodities, while consuming high value of imported goods being processed from this country's exported commodities. Significant political revolution towards better value chains, changes and processes of local products, DBI-ABI, would be extremely meaningful in providing value added to natural resources and individual workforce.

Considering the above description, therefore, it is very proud to claim that decentralizing and stabilizing the growth would only be made possible and guaranteed through ABI development. In addition to that, ABI would significantly support the nation in simultaneously providing the more appropriate pro: growth-job-poor-green development model, wherein the Working Cabinet, "Kabinet Kerja” is mainstreaming. Operational paradigm of "Kabinet Kerja" in mainstreaming food sovereignty could be taken as appropriate example. The only need nowadays is the existence of the true political-economic will to follow.

\section{THE ECONOMY IN DISARRAY: BEYOND 2010}

Five global criticisms on the Indonesia's economic growth, 2001-2010, could be seen as perfectly a set of myths due to the global economic recession precipitated by the PIGS, Portugal-Ireland-Greece-Spain, during the second half of the last decade, 2001-2010. However, very careful attention should have been properly formulated in response to possible renovation of the recession into global economic progress of the European countries and the US that could possibly be realized not any longer. This inflection point in time could mean serious calamity to the progress of economic growth in the decade after.

The symptomatic threat of massive capital flight started by the end of 2012. The country has been facing serious economic problems threatened by the drop in local currency. Such an economic collapse came into being in the mid of 2013. Continuing impact of such a local currency drop has been lasting until the end of this year, November 2015, without any significant symptom when to terminate. The Rupiah exchange rate dropped seriously from Rp 9,620 per US Dollar in January 2013 and Rp 10,333 early August 2013, to 12,191 at the end of 2013 (Subekti, 2013), escalated to Rp 14,700 in September and down back to Rp 13,680 per US Dollar, early November 2015.

Such a significant drop of local currency exchange rate of approximately 40.20 percent, 2013-2015, with no terminating indication has off course made the country's economy in disarray. Massive capital inflow and FDIs the decade before dramatically changed beyond 2010, into massive capital outflow and escalated the excessive demand for US Dollars. Supported by other need, and coupled with several political as well as speculative measures, the decrease in the Rupiah exchange rate becoming more and more dramatic, and jumped down into Rp 14,700 per US Dollars, before recovered back approaching the end of 2015.

Again, the statistics proved the fact that over dependent upon foreign-based economy as well as import-based industry, IBI, based on over-protective measures in favor of them, at the expense of DBI, has made the country's economy jumped down to its lowest level. As far as Rupiah exchange rate is concerned, the jump reached more than 40 percent during the last three years only. The latest fact strengthened the reminder raised long before that marginalizing DBI and particularly agricultural sector as the local potential of the common, for the sake of IBI industrialization has been very risky. 


\section{TOWARDS ECONOMIC DUALISM}

After assessing the inter-temporal economic performance of the Republic of Indonesia, before 2000, 2001-2010, and beyond 2010, several remarks could be taken as a serious lessons to learn for the purpose of taking prior recommendation needed to develop the nation more appropriately without blaming any regime under any political configuration. Time has been changing all over. Specific political configuration was always being dictated by its own mission and perspective. However, common lessons learned could be outlined in the followings.

The first lesson commonly characterizing the economic performance was the spirit for having the country's industrialization to take off, running after developed countries, especially after being blessed with oil boom windfall profit long before 2000. The second, the selection of industrial sector being prioritized was just the same all over the periods, even during this Reformation Government, which is prioritizing HTI, SLI, and CII, and concentrated very extremely on IBI, through overall over-protective measures, monetary-fiscal-trade and other policies.

The third lesson showed that such protective policies were very remarkably in favor of IBI, but at the same time, it must be accepted that it was at the expense of local economic potential, supported by natural resources and agricultural sector, commonly owned by every province in the Republic. The forth, the ultimate consequence of such an economic dichotomy, over-protecting IBI and at the same time marginalizing DBI, was the absence of exit strategy in anticipating any economic obstacles of the country. It could be easily observed that massive foreign earning should have been realized from agricultural export during currency crisis, was not been realized into being.

The fifth lesson, proved the fact that this country has been very long being trapped by its economic dichotomy policy which very fragile, over-dependent upon foreign countries, and proven to be relatively unstable. The seventh, as the consequence of such a dichotomy marginalizing local potential, the economy is being more and more concentrated in Jakarta only without meaningful economic growth outside Jakarta in general, and particularly outside Java. Relatively unstable, centralized in Jakarta, and at minimum value added, were common denominator characterizing the country's economy all over the economic periods concerned.

Based on the fact that economic dichotomy protecting massively the IBI is very much misleading, but acknowledging the impossibility of switching back to local sector dominated by the DBI and at the same time marginalizing IBI due to its dominance for the days, therefore, combining IBI and DBI under economic dualism policy would be the only alternative to survive the future of the Indonesian economy. Meaningful attention for developing DBI through agro-industrial development would consequently stabilize and decentralize the country's economic growth, and at the same time providing necessary value added for both the natural resource based industry as well as the unskilled labor intensive industry (Maksum, 2014).

\section{CONCLUDING REMARKS}

The economic policy strongly based upon sectorial dichotomy has been adopted by the Republic of Indonesia has been proven to be ineffective, if not misleading, in providing a relatively stable and decentralized growth among regions, communities and among people. Such a dichotomy between IBI and DBI has seriously spread sectorial injustice within its national development. Due to this fact therefore, such a dichotomy have to be terminated to end unjust development.

Shifting from such a dichotomy, promoting IBI while at the same time marginalizing DBI, towards economic dualism promoting both IBI and DBI very fairly could be recommended as alternative solution to renovate the country's economy. This selection would be strongly guaranteed by its economic power to stabilize and decentralize the growth, and at the same time provided an extra size of development bread sharable by the country's provinces and population.

Knowing the fact that poverty alleviation has been long live development program of this country at any political configuration, therefore, the shift from IBI to IBI-DBI, would be proper development model promoting DBI with its economic power in providing the pro: poor-job-people-green development model guaranteeing many other development 
objectives. It could be summarized then, that stabilizing and decentralizing the growth would only be possible via DBI.

The globe is changing. The Working Cabinet of Jokowi-JK Government has been proclaiming as mainstreaming, among others, on food and agro industry development. Legal standings have been formulated, and politically support the established Cabinet. However, they would never be sufficient unless being strongly supported by consistent political will of Jokowi-JK. However, the justifiability of the Cabinet would only be possible through the shift from IBI formerly adopted by previous regimes towards IBI and DBI as development dualism which have been popularized by Jokowi-JK during Presidential Election.

This shift needs no remarkable economic trade off, especially based on the country's macroeconomic perspective. Moreover, DBI promotion would deeply acknowledge the blessing from the Almighty for abundantly available resource endowment, natural and human capitals.

\section{REFERENCES}

Budiman, H. T. 2012. Indonesian Economic Outlook 2013 and Beyond. Presented at the workshop of Strategic Industries, Ministry of State Owned Enterprises (BUMN). Yogyakarta, 01 November 2012.

Jung, Ku-Hyun, P. Anuchat, M. Maksum; and T. Park. 2003. Civil Society Response to Asian Crisis-Thailand, Indonesia and Korea. IEWS, Yonsei University.

Maksum, M. 2012. Rakyat Tani Miskin: Korban Terorisme Pembangunan Nasional (Poor Farmers: Victim of Terrorizing National Development). PSPK-UGM, 2nd ed.

Maksum, M. 2013. Pembijakan Importasi Sapi Abadi (Politicizing Sustainable Meat Import). Gatra, a Political Magazine. 6 September 2013.

Maksum, M. 2014. Stabilizing and Decentralizing the Growth through Agro Industrial Development. Presented at the International Conference on Agroindustry, ICOA. Conducted by the Department of Agro-Industrial Technology, the Faculty of Agricultural Technology, University of
Gadjah Mada. Yogyakarta 24-25 November.

Oberman, R., R. Dobbs, A. Budiman, F. Thompson and M. Rossee. 2012. The Archipelago Economy: Unleashing Indonesia's Potentials. A publication of the McKinsey Global Institute, submitted to the GOI.

Subekti, W. 2013. Mengapa Nilai Tukar Rupiah Kian Melemah Terhadap Dolar . www.wibowopajak.com/2013/12/mengap a-nilai-tukar-rupiah-kianmelemah.html?m=1 